\title{
EVALUATION OF BIOCHEMICAL AND MICROBIOLOGICAL CHANGES OCCURRING IN FRESH CHEESE WITH ESSENTIAL OILS DURING STORAGE TIME
}

\author{
MELINDA FOGARASI ${ }^{a}$, SONIA A. SOCACI ${ }^{b}$, SZABOLCS FOGARASI ${ }^{c *}$, \\ MIRELA JIMBOREAN ${ }^{\mathrm{a}}$, CARMEN POP ${ }^{\mathrm{b}}$, MARIA TOFANĂ ${ }^{\mathrm{b}}$, \\ ANCA ROTAR ${ }^{b}$, DORIN TIBULCA ${ }^{a}$, DAN SALAGEAN ${ }^{a}$, \\ LIANA SALANTA ${ }^{b}$
}

\begin{abstract}
The current study aimed to determine the chemical composition and antibacterial activity of two essential oils extracted from herbs belonging to the family Lamiaceae (mint and oregano), and their beneficial impact on the biochemical and microbiological changes occurring in fresh cheese during storage time. Based on the essential oils results three types of fresh cheese were formulated and the consumer prefer sample were sensory evaluated using the 9-point hedonic test. In order to determine the stability during storage, the selected sample and the essential oil free control sample were sampled initially, after 6 and 12 days of storage than subjected to physicochemical (protein, fat, moisture, ash, total carbohydrates, and energy) and microbiological analyses (S. aureus, E. coli).
\end{abstract}

Keywords: Antibacterial activity, Biochemical changes, essential oils, microbiologic, sensory evaluation, storage, volatile profile

\section{INTRODUCTION}

In the recent years, cheese manufacturing and processing has transitioned from traditional art to science. Many of the cheese varieties have been developed and tested for different environmental conditions in order to meet the highly pretentious customer standards [1]. Fresh cheeses

a Department of Food Engineering, University of Agricultural Sciences and Veterinary Medicine of Cluj-Napoca, Cluj-Napoca, Romania, Calea Mănăştur 3-5, 400372 Cluj-Napoca, Romania

${ }^{b}$ Department of Food Science, University of Agricultural Sciences and Veterinary Medicine of Cluj-Napoca, Cluj-Napoca, Romania, Calea Mănăştur 3-5, 400372 Cluj-Napoca, Romania

c Babeş-Bolyai University, Faculty of Chemistry and Chemical Engineering, 11 Arany Janos Str., Cluj-Napoca, RO-400028, Romania

*Corresponding author: szfogarasi@chem.ubbcluj.ro 
production involves the enzymatic coagulation of milk with rennet and/or other coagulating enzymes, which in some cases are combined with specific lactic bacteria [2]. It is well known that soft texture, low salt content, high acidity and moisture, which are characteristics of fresh cheeses, favor the growth of spoilage microorganisms, leading to consumer rejection and possible economic losses for the industry. Moreover, fresh cheeses are considered potential vehicles for Escherichia coli, a pathogen able to survive and grow even at refrigerate temperature. As a result, the manufacturing of cheeses involves the addition of synthetic preservatives, (e.g., potassium and sodium sorbate) in order to ensure the safety of fresh cheeses [3]. However, many studies revealed the negative effects of synthetic food preservatives on human health and the increasing resistance of microorganisms to these compounds. As a result, researchers are focused on the identification and use of natural preservatives like essential oils (EOs), which are volatile liquids distilled from different aromatic plant materials [4-7]. EOs from Origanum vulgare $L$. (oregano - OrEO) and Mintha piperita (mint - MiEO) are effective in inhibiting a range of cheeserelated bacteria in vitro systems, making them a key alternatives for cheese preservation [8]. Considering the antioxidant activity and food preserving properties of OrEO and MiEO and the fact that they are natural products [7], which can be produced in organic condition, the selected EO could be used in organic food products with short shelf-life. Therefore, this study aimed to evaluate the physicochemical, microbiological and sensory aspects that characterized a fresh cheese made with the incorporation of OrEO and MiEO and the effects of these EOs on the cheese during refrigerated storage.

\section{RESULTS AND DISCUSSION}

\section{Chemical Composition of Essential Oils}

The volatile compounds detected by ITEX-GC/MS analysis in the two essential oils with their percentage composition are summarized in Table 1.

According to the results, the MiEO contained 39 constituents and the most important ones were $\alpha$-pinene $(3.57 \%), \beta$-pinene $(4.71 \%)$, Sabinene (2.04\%), D-limonene (13.06\%) and Eucalyptol (17.76\%), all of them belonging to the monoterpene hydrocarbons class. The obtained results are similar to the aromatic profile presented by de Sousa Barros et al. [8] regarding essential oils extracted from different Mentha species. Similarly, OrEO included 21 major components among which p-cymene (13.76\%), gamma terpinene $(11.94 \%)$, D-limonene (34\%) and thymol (19.38\%) had the highest concentration which is also confirmed by the data presented by Sahbaz A. et al. [9]. The thymol belongs to the oxygenated monoterpenes class and the rest of them to monoterpene hydrocarbons. 
EVALUATION OF BIOCHEMICAL AND MICROBIOLOGICAL CHANGES OCCURRING IN FRESH CHEESE WITH ESSENTIAL OILS DURING STORAGE TIME

Table 1. Volatile compounds profile of oregano and mint essential oils

\begin{tabular}{|c|c|c|c|}
\hline $\begin{array}{l}\text { Crt. } \\
\text { No. }\end{array}$ & Compound & \begin{tabular}{|c|} 
MiEO, \\
$\%$
\end{tabular} & $\begin{array}{c}\text { OrEO } \\
\%\end{array}$ \\
\hline 1. & Furan, 2,5-diethyltetrahydro- & 0.14 & - \\
\hline 2. & 2-Hexenal, (E)- & - & 0.29 \\
\hline 3. & Origanene & - & 2.37 \\
\hline 4. & alpha.-Thujene & 0.53 & - \\
\hline 5. & alpha.-Pinene & 3.57 & 1.51 \\
\hline 6. & Camphene & 0.15 & 0.39 \\
\hline 7. & 3-Methyl-cyclohexanone & 0.20 & - \\
\hline 8. & Sabinene & 2.04 & - \\
\hline 9. & beta.-Pinene & 4.71 & 0.24 \\
\hline 10. & beta.-Myrcene & 0.67 & 4.78 \\
\hline 11. & n.i. & 0.04 & - \\
\hline 12. & 1-Methylene-4-(1-methylethenyl)- cyclohexane & 0.07 & - \\
\hline 13. & Octanal & - & 0.20 \\
\hline 14. & alpha.-Phellandrene & 0.05 & 0.69 \\
\hline 15. & 3-Carene & 0.05 & 0.24 \\
\hline 16. & alpha.-Terpinene & 0.27 & 3.49 \\
\hline 17. & $p$-Cymene & 0.08 & 13.76 \\
\hline 18. & n.i. & 2.43 & - \\
\hline 19. & D-Limonene & 13.06 & 34.08 \\
\hline 20. & Eucalyptol & 17.76 & - \\
\hline 21. & beta-trans-Ocimene & 0.13 & 0.06 \\
\hline 22. & beta-cis-Ocimene & 0.03 & 0.10 \\
\hline 23. & gamma.-Terpinene & 0.51 & 11.94 \\
\hline 24. & n.i. & 0.16 & - \\
\hline 25. & Terpinolene & 0.13 & 0.32 \\
\hline 26. & Benzene, 2-ethenyl-1,3-dimethyl- & - & 0.06 \\
\hline 27. & beta.-Linalool & - & 0.62 \\
\hline 28. & Thymol & - & 19.38 \\
\hline 29. & Carvacrol & - & 5.28 \\
\hline 30. & Cyclohexanone, 5-methyl-2-(1-methylethyl)- & 30.54 & - \\
\hline 31. & Menthofuran & 2.06 & - \\
\hline 32. & Cyclohexanone, 5-methyl-2-(1-methylethyl)-, (2R-cis)- & 5.99 & - \\
\hline
\end{tabular}


MELINDA FOGARASI, SONIA A. SOCACI, SZABOLCS FOGARASI, MIRELA JIMBOREAN, CARMEN POP, MARIA TOFANĂ, ANCA ROTAR, DORIN TIBULCA, DAN SALAGEAN, LIANA SALANTA

\begin{tabular}{|c|l|c|c|}
\hline $\begin{array}{l}\text { Crt. } \\
\text { No. }\end{array}$ & Compound & $\begin{array}{c}\text { MiEO, } \\
\%\end{array}$ & $\begin{array}{c}\text { OrEO, } \\
\%\end{array}$ \\
\hline 33. & Cyclohexanol, 5-methyl-2-(1-methylethyl)-, (1.alpha.,2.alpha.,5.alpha.) & 0.86 & - \\
\hline 34. & Cyclohexanol, 5-methyl-2-(1-methylethyl)-, (1.alpha.,2.beta.,5.alpha.)-(.+--.)- & 9.63 & - \\
\hline 35. & Cyclohexanol, 5-methyl-2-(1-methylethyl)-, [1S-(1.alpha.,2.beta.,5.beta.)]- & 0.15 & - \\
\hline 36. & alpha.-Terpineol & 0.09 & - \\
\hline 37. & Pulegone & 0.38 & - \\
\hline 38. & Piperitone & 0.13 & - \\
\hline 39. & Cyclohexene, 4-methyl-1-(1-methylethyl)- & 0.10 & - \\
\hline 40. & Menthol, acetate & 2.14 & - \\
\hline 41. & Cyclohexane, 1-ethenyl-1-methyl-2-(1-methylethenyl)-4-(1-methylethylidene)- & 0.07 & - \\
\hline 42. & n.i. & 0.06 & - \\
\hline 43. & Caryophyllene & 0.88 & 0.17 \\
\hline 44. & alpha.-Caryophyllene & 0.02 & - \\
\hline 45. & Germacrene D & 0.07 & - \\
\hline 46. & n.i. & 0.02 & - \\
\hline TOTAL & 100 & 100 \\
\hline
\end{tabular}

MiEO- mint essential oil, OrEO - oregano essential oil

\section{Antibacterial Activity of Essential Oils}

In order to evaluate the antibacterial activity, minimum inhibitory concentration tests of the studied essential oils were performed. According to the results shown in Table 2, minimum inhibitory concentrations values differ significantly between the two essential oils.

Table 2. Minimum inhibitory concentrations (MIC) of essential oils

\begin{tabular}{|c|c|c|c|c|}
\hline \multirow{2}{*}{$\begin{array}{c}\text { Essential } \\
\text { Oil }\end{array}$} & $\begin{array}{c}\text { E. coli } \\
\text { ATCC 25922 }\end{array}$ & $\begin{array}{c}\text { S. aureus } \\
\text { ATCC 25923 }\end{array}$ & $\begin{array}{c}\text { S. enteritidis } \\
\text { ATCC 13076 }\end{array}$ & $\begin{array}{c}\text { L. monocytogenes } \\
\text { ATCC 19114 }\end{array}$ \\
\cline { 2 - 5 } & \multicolumn{4}{|c|}{$\mu \mathrm{l} / \mathrm{ml}$} \\
\hline MiEO & $0.56 \pm 0.0$ & $2.45 \pm 0.0$ & $1.59 \pm 0.0$ & $5.14 \pm 0.0$ \\
\hline OrEO & $0.22 \pm 0.0$ & $0.13 \pm 0.0$ & $0.27 \pm 0.0$ & $0.13 \pm 0.0$ \\
\hline
\end{tabular}

MiEO- mint essential oil, OrEO - oregano essential oil, E. coli - Escherichia coli, S. aureus Staphylococcus aureus, S. enteritidis - Salmonella enteritidis, L. monocytogenes - Listeria monocytogenes. Values are results of three replicates. Control negativ, were $0.11 \pm 0.0$ for E. coli (ATCC 25922) and $0.05 \pm 0.0 \mu \mathrm{g} \mathrm{GE} \mathrm{mL} \mathrm{mL}^{-1}$ for $S$. aureus (ATCC 25923), 0,24 \pm 0.0 for $S$. enteritidis, $0.11 \pm 0.0$ for $L$. monocytogenes . 
The results show that OrEO was the most bacteriostatic against all four of the selected bacteria, considering that it had the lowest MIC values. However, in the case of $E$. coli, the antibacterial activity of the two essential oils is comparable while for the other bacteria the differences are more significant. In the case of bacteria $S$. aureus and L. monocytogenes OrEO had the same antibacterial activity $(0.13 \mu \mathrm{l} / \mathrm{ml})$. The antibacterial activity of MiEO was also the most bacteriostatic against $E$. coli, followed by $S$. enteritidis, S. aureus and L. monocytogenes.

\section{Sensorial Analysis}

Considering that the sensorial quality of food products is a key factor in consumer's decision-making process, the Hedonic testing was used to determine consumer's attitude towards all three fresh cheese formulations samples by measuring the degree of acceptance of the new products. It is very important to note that the organoleptic properties of fresh cheese enhanced with essential oils remained acceptable to consumers and the quality level similar to the current commercially available products. This is also confirmed by the results shown in the Table 3 for sensorial evaluation of fresh cheese samples containing different type and level of essential oils compared to the control sample (without EOs).

Table 3. Results of sensorial evaluation

\begin{tabular}{|l|l|l|l|l|l|l|}
\hline \multicolumn{1}{|c|}{ Sample } & Appearance & Color & Texture & Odor & Taste & $\begin{array}{c}\text { Overall } \\
\text { acceptability }\end{array}$ \\
\hline C.S. & 7.1 & 7.0 & 6.2 & 7.2 & 7.1 & 6.9 \\
\hline CH. $\mathbf{0 . 0 3 \%}$ MiEO & 7.5 & 7.6 & 8.2 & 7.6 & 8 & 7.8 \\
\hline CH. $\mathbf{0 . 0 2 \%}$ OrEO & 7.0 & 7.0 & 6.4 & 6 & 7 & 6.6 \\
\hline
\end{tabular}

C.S. - control sample, $\mathrm{CH}$. $0.03 \%$ MiEO- cheese with $0.03 \%$ mint essential oil, $\mathrm{CH} .0 .02 \%$ OrEO - cheese with $0.02 \%$ oregano essential oil

It was found that the acceptability of the fresh cheese with $0.02 \%$ oregano essential oil was the lowest which can be attributed to the taste and the intense smell of OrEO. In contrast, the sample with $0.03 \% \mathrm{MiEO}$ had the highest acceptability score (7.8) as well as for the other organoleptic characteristics. The mint essential oil has given a fresh taste and smell to the product and it reduces the fatty taste of the product. Moreover, the sensorial evaluation revealed that fresh cheese with $0.03 \%$ MiEO achieved higher score than the control cheese sample. 
MELINDA FOGARASI, SONIA A. SOCACI, SZABOLCS FOGARASI, MIRELA JIMBOREAN, CARMEN POP, MARIA TOFANĂ, ANCA ROTAR, DORIN TIBULCA, DAN SALAGEAN, LIANA SALANTA

\section{The biochemical analysis of the fresh cheese}

The results of the biochemical analysis presented in Table 4 revealed that the physicochemical parameters for the cheese samples with and without MiEO were approximately the same during storage. It was observed that the gradual reduction in of cheeses moisture content during the storage led to an increase in total lipids, protein, and ash. According to the literature, this can be explained by the curd shrinkage, as a consequence of the acid production by starter culture, which helps to drain the whey from the cheese mass [3].

Table 4. The compositional parameters percentage values according to the ripening stages

\begin{tabular}{|c|c|c|c|c|c|c|}
\hline Sample & \multicolumn{3}{|c|}{ Control sample } & \multicolumn{2}{c|}{ Fresh cheese with $\mathbf{0 . 0 3 \%}$ MiEO } \\
\hline Storage time, day & $\mathbf{1}$ & $\mathbf{6}$ & $\mathbf{1 2}$ & $\mathbf{1}$ & $\mathbf{6}$ & $\mathbf{1 2}$ \\
\hline Fat, g/100 g & $27.5 \pm 0.1$ & $28.63 \pm 0.3$ & $30.17 \pm 0.1$ & $28 \pm 0.07$ & $29.04 \pm 0.04$ & $30.39 \pm 0.09$ \\
\hline Protein, g/100 g & $17.98 \pm 0.08$ & $19.11 \pm 0.1$ & $21.07 \pm 0.5$ & $18.14 \pm 0.1$ & $19.28 \pm 0.3$ & $20.97 \pm 0.2$ \\
\hline Moisture, g/100 g & $44.87 \pm 0.2$ & $43.08 \pm 0.06$ & $41.93 \pm 0.1$ & $45.48 \pm 0.05$ & $44.17 \pm 0.4$ & $42.96 \pm 0.03$ \\
\hline Ash, g/100 g & $2.6 \pm 0.04$ & $2.71 \pm 0.07$ & $2.85 \pm 0.01$ & $2.73 \pm 0.06$ & $2.8 \pm 0.02$ & $2.97 \pm 0.1$ \\
\hline $\begin{array}{c}\text { Total } \\
\text { carbohydrates, } \\
\text { g/100 g }\end{array}$ & $7.05 \pm 0.01$ & $6.47 \pm 0.2$ & $3.98 \pm 0.03$ & $5.65 \pm 0.02$ & $4.71 \pm 0.1$ & $2.71 \pm 0.08$ \\
\hline $\begin{array}{c}\text { Energy, } \\
\text { kcal/100 g }\end{array}$ & $347.62 \pm 0.09$ & $359.99 \pm 0.1$ & $371.73 \pm 0.2$ & $347.16 \pm 0.07$ & $357.32 \pm 0.1$ & $368.23 \pm 0.06$ \\
\hline
\end{tabular}

MiEO- mint essential oil

The biochemical analysis of the fresh cheese with and without MiEO has revealed that the fat percentage shows a consistent upper trend during the ripening stages, from $28.0 \pm 0.76 \mathrm{~g} / 100 \mathrm{~g}$ within first day of ripening to $30.39 \pm 0.09$ in the last stage (day 12).

\section{Microbiological evaluation of cheese during storage}

Quantitative detection of Escherichia coli (E. coli) and Staphylococcus aureus (S.aureus) was performed to establish the contribution of essential oil to the fresh cheese microbial load and to evaluate their safety. The European regulations on microbiological criteria for cheese preparations (European Union, 2005) contain limits for $E$. coli and S. aureus only. The results of fresh cheese microbiological examination, Table 5, indicate that MiEO has an important antimicrobial effect on the finished product in comparison to the control sample. 
EVALUATION OF BIOCHEMICAL AND MICROBIOLOGICAL CHANGES OCCURRING IN FRESH CHEESE WITH ESSENTIAL OILS DURING STORAGE TIME

Table 5. Microbiological characteristics of cheese formulations

\begin{tabular}{|c|c|c|c|}
\hline \multirow{2}{*}{ Sample } & Storage time & \multirow{2}{*}{ E. coli } & S. aureus \\
\hline & day & \multicolumn{2}{|c|}{ log CFU/g } \\
\hline \multirow{3}{*}{ Control sample } & 1 & $\mathrm{ABS}$ & 2.14 \\
\cline { 2 - 4 } & 6 & $\mathrm{ABS}$ & 2.34 \\
\cline { 2 - 4 } & 12 & $\mathrm{ABS}$ & 2.57 \\
\hline \multirow{2}{*}{$\begin{array}{c}\text { Fresh cheese with } \\
0.03 \% \text { MiEO }\end{array}$} & 1 & $\mathrm{ABS}$ & $\mathrm{ABS}$ \\
\cline { 2 - 4 } & 6 & $\mathrm{ABS}$ & $\mathrm{ABS}$ \\
\cline { 2 - 4 } & 12 & $\mathrm{ABS}$ & $\mathrm{ABS}$ \\
\hline
\end{tabular}

In the case of the fresh cheese with $0.03 \%$ MiEO, it can be seen that $S$. aureus is absent during storage which sustains the inhibitory effect of the MiEO. Moreover in the control sample $S$. aureus grow in the product during storage from 2.14-2.57 [log CFU/g. These findings clearly underline the beneficial impact of the addition of $0.03 \%$ MiEO on the biochemical and microbiological changes occurring in fresh cheese during storage time.

\section{CONCLUSIONS}

The present work proved that the incorporation of OrEO and MiEO can enhance the antimicrobial properties of fresh cheese during storage time, leading to the natural preservation of the product. Based on the results it can be concluded that OrEO was the most bacteriostatic against all four of the selected bacteria, due to the lowest MIC values, being followed by MiEO. On the other hand, sensory analysis revealed that the acceptability of the fresh cheese with $0.02 \%$ OrEO was the lowest while the sample with $0.03 \%$ MiEO had the highest acceptability score (7.8) due to the fresh taste and smell, which is related to the distinctive volatile profile of MiEO. As an overall conclusion it can be stated, the addition of $0.03 \%$ MiEO to the fresh cheese improves significantly its sensorial quality and stability during storage time, but without modifying the physicochemical parameters of the final product.

\section{EXPERIMENTAL SECTION}

\section{Plant Materials and Essential Oils Extraction}

The dried mint and oregano leaves were purchased from a company that markets food ingredients (Solina Group, Alba lulia, Romania). Essential oils were obtained by hydrodistillation using $50 \mathrm{~g}$ dried leaves for both plants. The 
MELINDA FOGARASI, SONIA A. SOCACI, SZABOLCS FOGARASI, MIRELA JIMBOREAN, CARMEN POP, MARIA TOFANĂ, ANCA ROTAR, DORIN TIBULCA, DAN SALAGEAN, LIANA SALANTA

extraction was performed for $3 \mathrm{~h}$ with $750 \mathrm{~mL}$ distilled water in a Clevengertype apparatus (S.C. Energo-Metr S.R.L., Odorheiu Secuiesc, Romania). The essential oils were dried over anhydrous sodium sulphate and stored at $4{ }^{\circ} \mathrm{C}$ until analysis.

\section{ITEX/GC-MS Analysis of Volatile Components}

The extraction of volatile compounds was performed using the intube extraction technique (ITEX) as described in our previous work [10] using $1 \mu \mathrm{L}$ of sample. The analysis of volatile compounds was carried out on a GCMS QP-2010 (Shimadzu Scientific Instruments, Kyoto, Japan) model gas chromatograph-mass spectrometer which can be used for measurement of various components including hydrogen [11], volatile organic compounds [12]. Next, the volatile compounds were separated on a Zebron ZB-5ms capillary column of $30 \mathrm{~m} \times 0.25 \mathrm{~mm}$ i.d. $\times 0.25 \mu \mathrm{m}$ film thickness. In all determinations, the carrier gas was $\mathrm{He}, 1 \mathrm{ml} / \mathrm{min}$ and the split ratio 1:20. The temperature program used for the column oven was: from $40 \mathrm{oC}$ (kept at this temperature for $2 \mathrm{~min}$ ) to $160{ }^{\circ} \mathrm{C}$ at $4{ }^{\circ} \mathrm{C} / \mathrm{min}$, then raised to $240{ }^{\circ} \mathrm{C}$ at $15^{\circ} \mathrm{C} / \mathrm{min}$ (kept at this temperature for $5 \mathrm{~min}$ ). The injector, ion source and interface temperatures were set at $250{ }^{\circ} \mathrm{C}$ and the MS mode was electron impact (EI) at ionization energy of $70 \mathrm{eV}$. The scanned mass range was 40-650 m/z. Volatile compounds were tentatively identified using the spectra of reference compounds from NIST27 and NIST147 mass spectra libraries and verified by comparison with retention indices drawn from www.pherobase.com or www.flavornet.org (for columns with a similar stationary phase to the ZB-5ms column). Compounds were considered "tentatively identified" only in the case in which their mass spectra similarity value was above $85 \%$. All peaks found in at least two of the three total ion chromatograms (TIC) were considered when calculating the total area of peaks (100\%) and the relative areas of the volatile compounds.

\section{Bacterial Strains}

The following microorganisms were tested: Escherichia coli (ATCC 25922), Staphylococcus aureus (ATCC 25923), Salmonella enteritidis (ATCC 13076) and Listeria monocytogenes (ATCC 19114). All strains were grown into a test tube containing $10 \mathrm{~mL}$ sterile nutrient broth (Oxoid Ltd., Basingstoke, Hampshire, England) at $37^{\circ} \mathrm{C}$ for $24 \mathrm{~h}$ in the case of E. coli, S. aureus and $S$. enteritidis, while $L$. monocytogenes at $37^{\circ} \mathrm{C}$ for $30 \mathrm{~h}$. The purity of the inoculums was confirmed by plating on appropriate selective media and microscopic examination of the Gram-stained smear (Optika microscope, B-252, M.A.D. Apparecchiature Scientifiche, Milan, Italy). A loopful of inoculums was transferred by streaking onto a selective medium: TBX for E. coli, BP (baird 
parker) for S. aureus, XLD agar (Oxoid Ltd., Basingstoke, Hampshire, England) for S. enteritidis and Palcam agar base (Oxoid Ltd., Basingstoke, Hampshire, England) with added Palcam selective supplement for $L$. monocytogenes. Plates were incubated at $44{ }^{\circ} \mathrm{C}$ for $24 \mathrm{~h} \mathrm{E}$. coli, at $37^{\circ} \mathrm{C}$ for $24 \mathrm{~h}$ in the case of $S$. Aureus, and $S$. enteritidis and at $37 \circ \mathrm{C}$ for $30 \mathrm{~h}$ in the case of $L$. monocytogenes. Bacterial morphology was confirmed by optical microscopy. Several colonies were collected with a sterile inoculating loop, transferred into sterile saline solution $\left(8.5 \mathrm{~g} \mathrm{~L}^{-1}\right)$, and adjusted to match the turbidity of a McFarland 0.5 standard $\left(1.5 \times 108 \mathrm{CFUmL}^{-1}\right)$ [31]. Then, three serial 10fold dilutions $\left(107,106\right.$, and $\left.105 \mathrm{CFU} \mathrm{mL}^{-1}\right)$ were prepared using the sterile saline solution as diluent.

\section{Fresh Cheese Manufacture}

All cheese samples were elaborated in the Experimental Laboratory of Dairy Products (pilot scale) of the Faculty of Food Science and Technology, Cluj-Napoca (University of Agricultural Sciences and Veterinary Medicine ClujNapoca, Romania). The control sample (fresh cheese without EOs) was obtained using 100 I of cow milk with $3.4 \%$ of fat content, which was previously pasteurized at $65^{\circ} \mathrm{C} / 30 \mathrm{~min}$ and cooled to $35^{\circ} \mathrm{C}$. Coagulation was performed at $35^{\circ} \mathrm{C}$ for 60 minutes using calcium chloride and $5 \mathrm{U}$ selected cultures of lactic bacteria (Lactococcus lactis ssp. lactis, Streptococcus thermophilus and Lactobacillus casei) and microbial enzyme rennet in form of two cubes [13]. Once the curd was formed, it was smoothly cut into $4-5 \mathrm{~cm}$ cubes and shredded with harp up to $6-8 \mathrm{~mm}$. The obtained curd was placed in perforated containers $\left(10 \mathrm{~cm}\right.$ diameter) for whey removal for $1 \mathrm{~h}$ at $18^{\circ} \mathrm{C}$. The cheese samples were vacuum packaged in sterile polyethylene bags and stored for 12 days in refrigerated storage at $4{ }^{\circ} \mathrm{C}$. The two types of fresh cheese with $0.02 \%$ oregano EO and $0.03 \%$ mint EO were obtained based on the above steps, like the control sample, with the only difference that the selected EOs were added in the stage of coagulation. The amount of essential oils (mint and oregano) used has been established after the microbiological analyzes results and composition of the EOs.

\section{Sensory evaluation of cheese}

Sensory characteristics of cheese samples were evaluated by a panel of 40 untrained assessors, with a mean age of 25 , consisted of students and staff members of the department. All samples were coded numerically and supplied in plastic dishes randomly. The 9-point hedonic scale test (1 being "dislike extremely" and 9 being "like extremely") was used to evaluate all cheese samples. The main sensory attributes used in the assessment of the samples were appearance, color, texture, odor, taste, and overall acceptability. 
MELINDA FOGARASI, SONIA A. SOCACI, SZABOLCS FOGARASI, MIRELA JIMBOREAN, CARMEN POP, MARIA TOFANĂ, ANCA ROTAR, DORIN TIBULCA, DAN SALAGEAN, LIANA SALANTA

\section{Physicochemical parameters of cheese}

The moisture, ash, total carbohydrates, total sugars, crude fat and crude protein of samples were determined according to AOAC procedures [14]. The cheeses samples moisture content was determined via drying in an oven at $105^{\circ} \mathrm{C}$ until constant weight while the ash content was established by incineration at $600 \pm 15^{\circ} \mathrm{C}$. The crude protein content of the samples was estimated by the micro-Kjeldahl method, in which the sample was digested with a known quantity of concentrated $\mathrm{H}_{2} \mathrm{SO}_{4}$ in the Kjeldahl digestion apparatus. The crude fat content was determined in accordance with the Gerber method described by SR ISO 488 [15]. The amount of total carbohydrate resulted as a difference based on the following equation: $100-(g$ moisture $+g$ protein $+g$ fat $+g$ ash). The total energy was calculated using the following equation from the literature: energy $(\mathrm{kcal})=4 \times(\mathrm{g}$ protein $+\mathrm{g}$ carbohydrate $)+9 \times(\mathrm{g}$ lipid $)[16,17]$.

\section{Microbiological evaluation of cheese}

Detection of Escherichia coli was carried out using the method described in SR EN ISO 16649-2:2007 standard (International Organization for Standardization, 2007, 2007b). Staphylococcus aureus was determined using the method described in SR EN ISO 6888-1:2002 standard (International Organization for Standardization, 2002). Total combined yeasts and moulds count (TYMC) was not determined, because the European regulations on microbiological criteria for cheese preparations (European Union, 2005) contain limits only for $E$. coli and $S$. aureus.

\section{ACKNOWLEDGEMENTS}

This work was supported by two grants of Ministry of Research and Innovation, CNCS-UEFISCDI, project number PN-III-P1-1.1-TE-2016-0973 and project number PN-III-P2-2.1-Cl-2018-0355.

\section{REFERENCES}

[1] F.A. Tabaran, S.D. Dan, A. Tabaran, C. Bele, C. Catoi, M. Borzan, G. Valasutean, M. Mihaiu, Studia UBB Chemia, 2015, 60, 4, 85.

[2] C.M. Asensio, N.R. Grosso, H. Rodolfo Juliani, LWT - Food Science and Technology, 2015, 60, 2, 664.

[3] H.T. Diniz-Silva, J. Batista de Sousa, J. da Silva Guedes, R.d.C. Ramos do Egypto Queiroga, M.S. Madruga, J.F. Tavares, E. Leite de Souza, M. Magnani, LWT - Food Science and Technology, 2019, 10.1016/j.Iwt.2019.01.039 
EVALUATION OF BIOCHEMICAL AND MICROBIOLOGICAL CHANGES OCCURRING IN FRESH CHEESE WITH ESSENTIAL OILS DURING STORAGE TIME

[4] L.-C. Salanta, M. Tofană, S.A. Socaci, E. Mudura, C. Pop, A. Pop, A. Cuceu, M. Nagy, Hop and Medicinal Plants, 2014, 1-2, 1.

[5] M. Nagy, S.A. Socaci, M. Tofană, C. Pop, C. Mureşan, A.V. Pop Cuceu, L. Salanţă, A.M. Rotar, Bulletin of University of Agricultural Sciences and Veterinary Medicine Cluj-Napoca. Food Science and Technology, 2015, 72, 1,

[6] C.A. Semeniuc, M.I. Socaciu, S.A. Socaci, V. Muresan, M. Fogarasi, A.M. Rotar, Molecules, 2018, 23, 9,

[7] N. Khorshidian, M. Yousefi, E. Khanniri, A.M. Mortazavian, Innovative Food Science \& Emerging Technologies, 2018, 45, 62.

[8] A. de Sousa Barros, S.M. de Morais, P.A.T. Ferreira, Í.G.P. Vieira, A.A. Craveiro, R.O. dos Santos Fontenelle, J.E.S.A. de Menezes, F.W.F. da Silva, H.A. de Sousa, Industrial Crops and Products, 2015, 76, 557.

[9] A. Sahbaz, H. Isik, O. Aynioglu, K. Gungorduk, B.D. Gun, European journal of obstetrics, gynecology, and reproductive biology, 2014, 177, 44.

[10] S.A. Socaci, C. Socaciu, C. Mureşan, A. Fărcaş, M. Tofană, S. Vicaş, A. Pintea, Phytochemical Analysis, 2014, 25, 2, 161.

[11] L.-C. Pop, L. Sygellou, V. Dracopoulos, K.S. Andrikopoulos, S. Sfaelou, P. Lianos, Catalysis Today, 2015, 252, 157-161.

[12] J. Dewulf, H. Van Langenhove, G. Wittmann, 2002, 21, 637.

[13] D. TTibulcă, M. Jimborean, A. Țibulcă, Romanian Biotechnological Letters, 2017, 10.26327RBL2017.67

[14] Official Methods of Analysis of AOAC INTERNATIONAL, 20th Edition ed., AOAC International; 20 edition.

[15] C.A. Semeniuc, A. Rotar, L. Stan, C.R. Pop, S. Socaci, V. Mireşan, S. Muste, CyTA - Journal of Food, 2015, 14, 2, 213.

[16] M. Fogarasi, S.A. Socaci, F.V. Dulf, Z.M. Diaconeasa, A.C. Farcas, M. Tofana, C.A. Semeniuc, Molecules, 2018, 23, 12

[17] M. Nagy, C.A. Semeniuc, S.A. Socaci, C.R. Pop, A.M. Rotar, C.D. Salagean, M. TofanĂ, Food Science and Technology, 2017, 37, 2, 315. 
